\title{
International bond markets and the introduction of the euro
}

Citation for published version (APA):

Kool, C. J. M. (2000). International bond markets and the introduction of the euro. METEOR, Maastricht University School of Business and Economics. METEOR Research Memorandum No. 011 https://doi.org/10.26481/umamet.2000011

Document status and date:

Published: 01/01/2000

DOI:

10.26481/umamet.2000011

Document Version:

Publisher's PDF, also known as Version of record

\section{Please check the document version of this publication:}

- A submitted manuscript is the version of the article upon submission and before peer-review. There can be important differences between the submitted version and the official published version of record.

People interested in the research are advised to contact the author for the final version of the publication, or visit the DOI to the publisher's website.

- The final author version and the galley proof are versions of the publication after peer review.

- The final published version features the final layout of the paper including the volume, issue and page numbers.

Link to publication

\footnotetext{
General rights rights.

- You may freely distribute the URL identifying the publication in the public portal. please follow below link for the End User Agreement:

www.umlib.nl/taverne-license

Take down policy

If you believe that this document breaches copyright please contact us at:

repository@maastrichtuniversity.nl

providing details and we will investigate your claim.
}

Copyright and moral rights for the publications made accessible in the public portal are retained by the authors and/or other copyright owners and it is a condition of accessing publications that users recognise and abide by the legal requirements associated with these

- Users may download and print one copy of any publication from the public portal for the purpose of private study or research.

- You may not further distribute the material or use it for any profit-making activity or commercial gain

If the publication is distributed under the terms of Article $25 \mathrm{fa}$ of the Dutch Copyright Act, indicated by the "Taverne" license above, 


\title{
INTERNATIONAL BOND MARKETS
}

\section{AND THE INTRODUCTION OF THE EURO}

\author{
Clemens J.M. Kool \\ March 2000
}

\begin{abstract}
In this paper, I analyze the consequences of the introduction of the Euro for the optimal composition of international bond portfolios and subsequently for the Euro/dollar exchange rate. For this purpose I apply a simple mean-variance approach using daily bond and exchange rate data over the period 1996-1998. First, I construct an optimal benchmark portfolio for representative investors from the U.S., Japan, the U.K., and the three major European countries participating in the Euro, France, Germany and Italy. Subsequently, I distinguish three plausible (Euro) exchange rate scenarios and three plausible (European) bond market scenarios as a result of the coming of the Euro. Then, the portfolio optimization is implemented again under the nine scenarios. Generally, the outcomes suggest that an increase in net demand for Euro-denominated bonds is unlikely, due to the inherent reduction of attractive diversification possibilities. For a given Eurobond supply this in turn suggest a depreciation of the Euro. Potential entry of the U.K. into the Euro area is not seen to change the results. Finally, I show that both actual supply and demand developments in international bond markets in 1999 are consistent with the observed depreciation of the Euro relative to the U.S. dollar.
\end{abstract}

Clemens J.M. Kool is a professor of Money and Banking at Maastricht University, the Netherlands. This paper was written when he was a visiting professor at the Federal Reserve Bank of St. Louis in 1999. Vincent de Boer collected data, while Katharina Haaf assisted in an exploratory analysis. Thomas A. Pollmann provided research assistance. Correspondence address: Department of Economics, University Maastricht, P.O. Box 616, 6200 MD Maastricht, the Netherlands. E-mail c.kool@,algec.unimaas.nl 


\section{Introduction}

On January 1, 1999 the Euro was formally introduced in 11 countries of the European Union. At that date, the European Central Bank (ECB) received control over monetary policy in the Euro area. Only the United Kingdom, Denmark and Sweden voluntarily opted-out for the moment, while Greece was deemed not ready for entry.

Obviously, the introduction of the Euro will have significant consequences for international investors' demands for assets denominated in different currencies. Portes and Rey (1998) for instance predict that international investors will increase the demand for Euro assets when European markets get deeper and more liquid with lower transaction costs. When relative asset supplies react slower than demands, Portes and Rey predict sizable exchange rate effects as well. Portes and Rey (1998), McCauley and White (1997) and McCauley (1997) all stress the key role of European bond markets compared

to the U.S. bond market. Internationally, trading in bonds substantially dominates trading in equity or real trade flows. McCauley (1997) explicitly distinguishes between asset managers and liability managers in this respect. In his view, issuers of debt currently prefer the U.S. market because of lower transactions costs and higher liquidity. However, with increasing size and integration of the European bond markets, debt issues might be increasingly denominated in Euros.

For managers of a diversified asset portfolio an additional argument plays a role. Not only liquidity and transactions cost, but also the correlation structure between bond returns of different currency denomination and between bond and exchange rate returns is of crucial importance. If a new Euro bond market would offer diversification opportunities not yet available in the current constituent bond markets, a substantial increase in demand for Euro assets might occur. On the other hand, if the creation of a common European currency yields a net reduction of diversification possibilities in European assets, demand for Euro assets could decrease. Masson and Turtelboom (1997) use a simple mean-variance framework to address this issue and conclude that central banks may rearrange their portfolio of official reserves by decreasing their dollar share and correspondingly increasing the Euro share. In this paper, private investors' optimal portfolio composition is the prime focus. Thereby, I apply the same mean-variance 
technique that Masson and Turtelboom (1997) use. Contrary to Masson and Turtelboom, I find that the correlation structure of bond and exchange rate returns may lead to a reduction in the net demand for Euro assets for a number of plausible scenarios.

The analysis has implications the dollar value of the Euro as well. Over the course of 1999, the Euro has gradually depreciated by more than 15 percent. Just before the start of the year 2000, the Euro even was quoted briefly at parity against the dollar. One often-mentioned reason for the behavior of the Euro/dollar exchange rate is the higher rate of economic growth in the United States as compared to Europe over the past year. However, one should recognize that the spot exchange rate between the Euro and the dollar in the short term will be determined by the market mainly in order to equilibrate stock supply and demand for assets denominated in these currencies. Consequently, a reduction of international diversification potential due to the introduction of the Euro may also have contributed to the decline of the Euro. I pursue this issue in the article as well. For this purpose, I use a number of alternative exchange rate scenarios in combination with a number of bond market scenarios. Note that only tentative conclusions can be drawn given the limited scope of the analysis.

Finally, the consequences of the introduction of the Euro on international investors' (net) demand for Euro-denominated assets will have an impact on the broader issue whether the Euro in the future will be able to compete with the U.S. dollar for the position of international reserve currency. Current research on this issue includes McCauley (1997), McCauley and White (1997), Prati and Schinasi (1997), Masson and Turtelboom (1997), Portes and Rey (1998), Tavlas (1998) and Hartmann (1998). Most of these contributions take a cautious position in predicting the future role of the Euro. The consensus appears to be that the U.S. dollar is more than likely to momentarily maintain its predominant role as the world's only international currency. On the other hand, the scope for the Euro to compete with the dollar in this field is generally acknowledged. Important determinants in this respect are a low and stable inflation environment in Europe, supported by a credible central bank policy, political stability, and more integrated European financial markets providing depth and liquidity at lower transaction costs, comparable to U.S. financial markets. Here, I abstract from a deeper analysis in this direction. 
The setup of the article is as follows. For the purpose of the actual analysis, I first develop a simple mean-variance utility framework that international investors may use for optimal portfolio diversification. Subsequently, I present daily bond and foreign exchange rate data of six of the world's major currencies - the U.S. dollar, the Japanese yen, the U.K. pound, the German mark, the French franc and the Italian lira - for the period from January 1996 through June 1999. Data from the 1996-1998 period preceding the introduction of the Euro will be used to compute optimal benchmark portfolios for investors from different countries. Since international capital flows with respect to bond markets are significantly larger than capital flows related to equity markets, money markets or goods markets (see for example Portes and Rey (1998), McCauley (1997), and McCauley and White (1997)), I exclusively focus on the various bond markets. The data are used to evaluate a number of plausible hypothetical scenarios with respect to the developments of both the Euro bond market and the Euro foreign exchange market. A brief summary and concluding remarks end the paper.

\section{Portfolio Optimization}

In the analysis, I assume that a representative investor in the United States optimizes an international bond portfolio, consisting of domestic (US), Japanese (JP), British (UK), German (GE), Italian (IT) and French (FR) bonds, with corresponding currency denomination. The investor maximizes a quadratic utility function of the following form: ${ }^{1}$

$$
\operatorname{Max} U=E\left(R_{p}\right)-\frac{1}{2} \operatorname{Var}\left(R_{p}\right),
$$

where $\mathrm{E}($.$) is the expectations operator, \operatorname{Var}($.$) is the variance and R_{p}$ is the portfolio return in U.S. dollars, which is defined as:

$$
R_{p}=\sum_{i} \alpha_{i}\left(R_{i}-e_{i}\right), i=F R, G E, I T, U K, J P, U S
$$

\footnotetext{
1 This model does not necessarily describe actual investment behavior. It answers the question what portfolio a risk-averse investor (with an Arrow-Pratt measure of absolute risk aversion equal to 2) would choose if these bonds were the only assets he could invest in. In reality, an investor has a wider range of assets and may use some form of the international CAPM. For the current exposition, the mean-variance approach suffices and has the added advantage of simplicity and tractability.
} 
where $R_{i}$ represents the percentage return on the country $i$ bond expressed in country $i$ 's currency, and $e_{i}$ is the percentage change in the exchange rate between currency $i$ and the U.S. dollar. The exchange rate is defined here as the amount of foreign currency per U.S. dollar, so that a rise indicates an appreciation of the dollar and a capital loss on foreign investments. ${ }^{2}$ The term in parentheses $\left(R_{i}-e_{i}\right)$ thus represents the return on country $i$ 's bond expressed in U.S dollars. ${ }^{3}$

The U.S. investor maximizes Equation 1 with respect to portfolio weights $\alpha_{i}$ subject to the constraints that

$$
\sum_{i} \alpha_{i}=1, \text { and } \alpha_{i} \geq 0, i=F R, G E, I T, U K, J P, U S
$$

The first restriction ensures that the portfolio shares sum to one. The inequality restrictions require positive portfolio shares and essentially are non-borrowing constraints. That is, a country's investors are unable (in net terms) to borrow in one currency (issue bonds in that denomination) and invest the proceeds in bonds with a different currency denomination.

Representative investors in each of the other five countries are assumed to perform a similar optimization procedure. Investors in all countries share the same quadratic utility function. However, each takes a different perspective due to the preferred currency denomination. While a U.S. investor optimizes a dollar-denominated portfolio, a German investor optimizes a German mark-denominated portfolio (after 1998, a Euro-denominated portfolio). Since expected returns and the covariance structure of bond returns and exchange rate returns depend on the currency of denomination, investors from different countries with correspondingly different benchmark currencies will obtain different optimal portfolios.

Obviously, this deviates from the standard result in international capital asset pricing models. Under the extreme assumptions of homogeneous preferences of investors irrespective of their country of residence and perfect validity of purchasing

\footnotetext{
${ }^{2}$ For the U.S dollar itself, the exchange rate change $e_{i}$ is of course zero and falls out.

${ }^{3}$ The term $\left(R_{i}-e_{i}\right)$ only approximates the true return, because the cross product of the bond and exchange rate return is neglected. For small (daily) returns the effect is marginal and the approximation appropriate.
} 
power parity, such models lead to the conclusion that investors choose a common global portfolio, see for instance Adler and Dumas (1983). In practice, country-specific factors appear to remain quite important in investment decisions, as witnessed by the well-known "home-bias" in asset portfolios, see Lewis $(1995,1999)$ and the importance of countryfactors in asset pricing, see Heston and Rouwenhorst (1994) and de Ménil (1999). Also, deviations from PPP abound and are strongly persistent, see Mussa (1986), Abuaf and Jorion (1990), and Frankel and Rose (1996).

Some further limitations and qualifications of the approach chosen here deserve discussion. First, no attempt is made to impose a market clearing condition for each bond market. Investors from each country optimize under the restriction formulated in Equation 3 only. That is, each representative investor is free to distribute his wealth across the six different bonds. No explicit account is given to the fact that the existing stock of bonds in any currency must be held by all investors jointly. Theoretically, this would require an additional restriction across investors from different countries that the sum of their portfolio demand for a given type of bond equals exogenous supply. If not, excess supply or demand would result with consequences for the level of bond prices or exchange rates. Second, I disregard the additional restriction that follows from the Balance-of-Payments identity for each country. In theory, a country's net asset position must be equal to its cumulated current account deficit.

Third, only private sector portfolio demands are analyzed. Central bank behavior is not taken into account. ${ }^{4}$ Fourth, the supply of bonds is for the moment taken to be exogenous. I will return to this issue when discussing actual events in 1999. Fifth, no attention is paid to other internationally traded assets like money market instruments, stocks and derivatives. Sixth, other market characteristics like different levels of liquidity and transactions costs are excluded from the analysis for simplicity.

To rationalize the neglect of the two additional constraints mentioned above, consider the following. First, especially the stock of domestic bonds but also the net issue of domestic currency bonds in each country generally far exceed the corresponding stocks and new issues of international bonds. If the international bond market segment

\footnotetext{
${ }^{4}$ See Masson and Turtelboom (1997) who perform a similar portfolio analysis with respect to central banks' holding of international reserves. Note that private asset holdings dwarf central bank reserves.
} 
for a currency is indeed only a small part of the total bond market in the same currency, it appears reasonable to assume that yields to maturity on representative bonds in each currency are determined in the national (domestic) bond markets. Then, international investors are price-takers in each bond market and are unconstrained in their portfolio choice. For the foreign exchange market, the situation is slightly different. Although the formal constraint is on the total capital account for each country (and currency) including foreign direct investment, short-term money market investment etc, the impact of capital flows related to international bond markets may be sufficiently large to influence exchange rate behavior. Nevertheless, I abstract from formally imposing a budget constraint on the capital account. It would require specification of other international financial investment flows as well. Instead, in the subsequent analysis, I will pay attention to the direction in which the exchange rate will move because of changes in the desired bond portfolios of international investors. This way, the neglect of the formal budget constraint in the analysis is used ex post to indicate potential pressure on the exchange rates.

\section{Data}

A standardized (total returns) bond price index for constant maturity 10-year government bonds has been obtained from DATASTREAM for the six countries involved, France, Germany, Italy, Japan, the United Kingdom and the United States for the period January 1, 1996 through June 29, 1999 on a daily frequency. ${ }^{5}$ For the same period and frequency, bilateral U.S. dollar exchange rates have been collected from DATASTREAM for the other five countries. Subsequently, daily percentage bond and exchange rate returns are computed to facilitate the analysis as described previously. Bond returns are total returns including reinvestment. For the empirical analysis, we initially only use the data from the period January 1, 1996 through December 31, 1998. This three-year period consisting of 783 daily observations precedes the formal introduction of the Euro on January 1, 1999. This benchmark period will be the basis for the simulations. In the last section I will use

\footnotetext{
${ }^{5}$ Government bond issues account for about 20 percent of all international bond issues only. Other major issuing parties are financial institutions, corporations and international institutions. However, I assume that the currency of denomination is the major distinguishing characteristic of bond returns and covariance
} 
the data from January 1 through June 29, 1999 to investigate the actual short-run impact of the introduction of the Euro on the characteristics of bond and exchange rate returns. ${ }^{6}$

[Insert Table 1 here]

In Panel A of Table 1, I present an overview of the return characteristics over the 1996-1998 benchmark period. I report means and standard deviations of bond returns expressed in their own respective currency, dollar denominated exchange rate returns and bond returns expressed in U.S dollars. A few points stand out. Over the benchmark period, bond returns have been substantially higher than on average over the past four decades, ranging from 0.025 percent per day (equal to 6.53 percent per year) for Japan to 0.078 percent (or 20.36 percent per year) for Italy. Standard deviations of daily bond returns are of comparable magnitude across countries, with the United States showing the highest variability.

\section{[Insert Figure 1 here]}

In all countries, the period 1996-1998 was characterized by declining bond yields, as witnessed by Figure 1. ${ }^{7}$ The corresponding rise in bond prices has yielded considerable capital gains to bondholders. This has been most prevalent in Italy. There, convergence to German interest rate levels occurred in anticipation of EMU, leading to above average returns in the transition period. Figure 1 also shows that European bond returns became closer aligned over the sample. This holds for the United Kingdom as well as for the countries participating in the Euro since January 1999. Note, though, that bond yields and (co-)variability still differ among the three Euro members, pointing to different risk characteristics of German, French and Italian government bonds. It implies absence of an integrated homogeneous European bond market in 1999.

In the foreign exchange market, the U.S. dollar appreciated on average against all currencies over the period, except against the British pound. Panel A in table 1 shows that the latter appreciated by 0.009 percent per day ( 2.35 percent annually) against the

structures. Then, government bond returns will be an approximation of bond returns in general in a specific currency.

${ }^{6}$ Note that all returns are nominal. Inflation differentials play no role in the analysis because investors convert all returns into their own currency prior to optimization.

${ }^{7}$ The data plotted in figure 1 are end-of-month yields to maturity on long-term government bonds from the St. Louis Federal Reserve Bank database and are not the same as the return data in the analysis. 
dollar. The dollar gained 0.019 percent per day (4.96 percent annually) against the German mark, however, and 0.011 percent per day ( 2.87 percent annually) against the yen. Especially noteworthy is the high variability of the dollar/yen exchange rate. Its standard deviation is almost twice that of the other currencies. Figure 2 provides a graphical representation of this point. ${ }^{8}$ Note that the three Euro members share the same exchange rate (in Euro's) against the dollar from January 1999 onward.

[Insert Figure 2 here]

From a dollar perspective, Japanese bond investments carried lowest returns and highest variability. French, German and U.S. bonds showed intermediate mean returns, with U.S. bonds having the lowest variation. Finally, U.K. and Italian bonds had high returns and intermediate variance.

To fully judge the relative attractiveness of the different bonds, information on the correlation structure of bond and exchange rate returns is required. This information is captured in Panels B through D of Table 1. ${ }^{9}$ From Panel B, it follows that the correlation coefficients between Japanese bond returns and bond returns in other countries are relatively small though still significant apart from the correlation between Japan and Italy. For the other countries, correlation coefficients are positive and generally higher, especially between the three Euro-countries and bilaterally between the U.S. and the U.K. With respect to the exchange rate returns in Panel C, all correlation coefficients are significantly positive. Again, the behavior of the three currencies in the Euro area stands out; they are almost perfectly correlated. Panel D shows that bond returns for the three Euro-countries (Germany, France and Italy) have higher positive correlation coefficients when expressed in one common currency - the U.S. dollar - than when expressed in their own currency. This is due to the unifying effect of the positively correlated foreign exchange returns on all bonds. For U.S. investors the correlation of U.S. bond returns with foreign bond returns decreases when taking the foreign exchange effect into account. The only strongly positive correlation that remains for the U.S. is with U.K. bonds. Obviously, the low correlation coefficients in the last column of Panel D indicate the

\footnotetext{
${ }^{8}$ Again, the data used in figure 2 for illustration are end-of-month data from the St.Louis Federal Reserve Bank database and not the data used in the (daily) analysis.

9 To assess the significance of the computed correlation coefficients at the 95 percent level, we use the value $2 / \sqrt{ } \mathrm{N}$ (equal to 0.071 for $\mathrm{N}=783$ ) as a rough approximation of the critical level.
} 
potential of profitable international diversification for U.S. investors. ${ }^{10}$ We now turn to the implementation of such diversification strategy.

\section{The Benchmark Portfolio}

To implement portfolio optimization as formulated in Equations 1-3, one needs both the covariance matrix of bond returns expressed in the currency of the investor and the vector of expected returns on the different bonds. To assess the impact of the introduction of the Euro, I first compute an optimal benchmark portfolio. For this, I first assume that the covariance matrix of returns as derived from the 1996-1998 data can be used at the end of 1998 for the optimal portfolio in 1999 - for the moment abstracting from the Euro's emergence. Second, I assume that neither changes in the long-term yield to maturity on government bonds nor the change in (the logarithm of) the exchange rate level are predictable. This assumption is strongly supported by empirical evidence that suggests that (logarithmic) exchange rates and long-term interest rates are characterized by random walk behavior. Theoretically, the pure expectations theory implies marginal predictability of changes in bond rates, while interest rate parity implies marginal predictability of changes in the spot exchange rate. For the foreign exchange market, interest rate parity actually suggests that the forward rate is a better predictor of the future spot rate than the current spot rate. Empirical support for the expectations theory and interest rate parity is generally lacking. Consequently, the assumption of unpredictability of future changes is warranted in my view. Therefore, the analysis takes expected exchange rate returns to be zero, while expected bond returns for 1999 expressed in own currency equal the yield to maturity as quoted at the end of 1998. Note that investors take into account both expected returns and the covariance matrix in this portfolio decision. Since they are risk averse they trade off high expected returns against high (co)variability and do not simply select the highest yielding bond.

[Insert Table 2 here]

Table 2 exhibits the computed optimal portfolio composition for investors from each of the six countries, based on the above assumptions. The U.S. optimal portfolio, for instance, consists of U.S. bonds for 60 percent only; the rest of the portfolio is almost

\footnotetext{
${ }^{10}$ Qualitatively similar correlation matrixes for the other currencies remain unreported. Clearly,
} 
equally split between German, Italian, U.K., and Japanese bonds. French bonds are excluded totally. The U.K. portfolio is also quite diversified, although it excludes French and Italian bonds. On the other extreme is the Japanese portfolio, which consists of foreign assets for only 10 percent despite the low expected return on Japanese bonds compared to that in other countries. For the Japanese, neither U.K. nor German bonds are interesting. Foreign investment is in approximately equal proportion in U.S., French and Italian bonds. The reason for the low degree of Japanese international diversification is the high volatility of the yen relative to other currencies. Although international diversification into assets that are only weakly correlated with Japanese bonds by itself reduces overall portfolio risk, the yen variability increases return variability and corresponding risk.

The continental European countries internationally diversify more than all other countries, at least when considered in separation. However, all three mainly invest in the other continental countries' bonds, with on average only 18 percent of the portfolio invested in the U.K., the U.S. and Japan. The column denoted EUR in Table 2 is the simple average of the first three portfolios and not the result of optimization. In the remainder of the paper, only the "continental-European" investor will be relevant, so the "EUR"-column provides the average European behavior. Note that in terms of investments outside the Euro-area France, Germany and Italy behave quite similar. Thus, their aggregation into a European investor seems appropriate.

\section{Scenario Analysis}

With the introduction of the Euro, the set of currencies in the current analysis is reduced from six to four. The three continental European countries in the sample now share the same currency that has replaced German mark, French franc and Italian lira respectively. The relevance of this event from a portfolio perspective is that it may have changed the covariance structure of exchange rate returns. If so, optimal portfolios will change too.

In the bond markets still six distinguishable categories of bonds exist. That is, German, French and Italian (government) bonds do not necessarily become perfect substitutes despite their common denomination in Euros. Nevertheless, the covariance 
structure of bond returns may have changed due to the Euro with consequences for portfolio composition.

\section{A Four Currency Scenario}

Clearly, an unlimited number of hypothetical scenarios with respect to the new covariance structure of bond and exchange returns can be developed. Practically, only a few of these can be investigated. In this paper, I distinguish three alternative behavioral assumptions with respect to the Euro exchange rate and three alternative assumptions with respect to the behavior of European bond returns, respectively. In total this yields nine different scenarios, one for each pair of assumptions.

With respect to the Euro's behavior I first assume that the Euro will be mimicking the past behavior of the German mark (DM), motivated by the past dominance of the German mark in the European exchange rate system and by the strong role of the mark in international financial markets. This so-called "Euro=DM" scenario may come through when the European Central Bank (ECB) inherits both the reputation and the policy approach of the German Bundesbank. Secondly, the Euro is assumed to behave as an equally weighted average of the three main participating currencies, the German mark $(\mathrm{DM})$, the French franc $(\mathrm{FF})$, and the Italian lira (IL). This is the "Euro= $(\mathrm{DM}+\mathrm{FF}+\mathrm{IL}) / 3$ " scenario. In this alternative, the Euro and European monetary policy may be thought of as a mix of the preferences of the participating countries. Suggestively, it could be associated with a weaker Euro and more accommodating monetary policy. Thirdly, I again assume that the Euro will behave as the German mark though with a higher variability, comparable to the variability of the dollar/yen exchange rate (the "Euro=DM with high variance" scenario). If a true tri-polar international foreign exchange system would emerge with little or no policy coordination, the bilateral exchange rates of the three main economic blocks might become more variable as they would to a larger degree act as buffer for asymmetric shocks. Based on the evidence in Table 1, I assume the dollar/Euro standard deviation to be 1.6 times as large as the dollar/DM standard deviation in this scenario.

With respect to the European bond markets, I start with the assumption that the bond markets are not affected by the introduction of the Euro. Investors then still choose 
from a set of six different bonds, of which three are denominated in the same currency ("3 Euro bonds"scenario). However, these three are imperfect substitutes. Note that German, French and Italian investors all choose the same portfolio now as their mutual exchange rate risk has disappeared completely. They face the same expected return vector and the same covariance matrix. In the second and third bond scenario, I assume that one large European bond market will emerge where bonds issued by individual governments become perfect substitutes. In the second scenario, the typical European bond behaves as the former German bond ("1 Euro bond: GE"); in the third scenario, it is similar to the equally weighted average of German, French and Italian bonds ("1 Euro bond: $(\mathrm{FR}+\mathrm{GE}+\mathrm{IT}) / 3$ "). Note that the latter two scenarios are logical counterparts to two of the exchange rate scenarios.

[Insert Table 3 here]

The results of the portfolio analysis under the nine different scenarios are presented in Table 3. The table consists of Panels A through C, corresponding to each of the foreign exchange scenarios for the Euro. Within each panel, the various bond scenarios are presented. Holdings of French, German, and Italian bonds respectively are aggregated into one category of European bonds. Of course, the desired portfolio composition within this European aggregate will differ across investors of different nationalities outside the Euro area. However, that will at most affect the relative price of the three European bonds, not the Euro exchange rate. Since the latter is the focus of analysis here, aggregation across European bonds is warranted.

A comparison of the benchmark portfolio in Table 2 and the different scenarios in Table 3 yields a number of conclusions. First, U.K. and Japanese optimal portfolios are relative insensitive to different assumptions about bond and foreign exchange rate behavior, as opposed to U.S. and European portfolios which show considerably more variation across scenarios.

Second, especially when the Euro/dollar exchange rate becomes more variable (Panel C), the relative attractiveness of the Euro is predicted to decline. U.S. investors reduce their Euro-bond holdings from 19 percent in the benchmark to about 3 or 4 percent; for Japanese investors the corresponding reduction is from 7 to 4 or 5 percent while for the U.K. investor the reduction is from 14 to 8 percent. On the other hand, 
continental European demand for U.K., Japanese and U.S. bonds declines with an amount of 10 to 13 percent of the total European portfolio. Reliable figures on the relative size of investment portfolios (expressed in a common currency) are lacking. Nevertheless, the overall result in the case of a variable Euro exchange rate appears to suggest less demand for Euros from a portfolio perspective, and a potential drop in the value of the Euro in international financial markets.

Third, when a unified European bond market would emerge with the typical European bond behaving like the past German bond, the analysis unambiguously predict lower overall demand for Eurobonds and a decline in the foreign exchange value of the Euro. On the one hand, both Japanese and U.S. investors demand less Eurobonds, while on the other hand European investors demand more Japanese and U.S. bonds. If the typical homogeneous European bond would behave as a weighted average of the previous national government bonds, hardly anything would change relative to the benchmark.

Overall, our hypothetical portfolio analysis does not suggest an immediate rise in the external value of the Euro. In the more favorable scenarios, the value of the Euro may be expected to remain approximately the same, while in some of the other scenarios, a drop in the foreign exchange value of the Euro is more likely. The underlying intuition is that the introduction of the Euro in combination with potential integration of European bond markets may decrease diversification possibilities within Europe. That is, for a German investor the disappearance of the bilateral exchange rate between Germany and Italy as well as the convergence between Italian and German bond behavior cause German and Italian bond returns expressed in Euros to be higher correlated than before. Consequently, within Europe diversification gets less rewarding and European investors may turn outside, thereby increasing the demand for non-Euro assets. Non-European investors on the other hand see their diversification possibilities across European countries diminish as well and may turn elsewhere too. Both effects may lead to lower demand for Euro assets and a depreciation of the Euro. Lower transaction costs and higher liquidity of more integrated European markets which have been excluded from the analysis may counteract this effect. 


\section{Entry of the U.K. Into the Euro Area}

Currently, the Euro area consists of 11 out of $15 \mathrm{EU}$ countries only. Especially the optout of the United Kingdom has attracted much attention and discussion, due to the rather special position of the U.K. While the entry of relatively small countries like Denmark, Sweden and Greece may not be expected to substantially impact the performance of the Euro, the entry of the U.K. into the Euro area could make a real difference, see for example Hartmann (1998). This is due to the fact that the U.K. currently has deeper and more liquid financial markets than any of the countries participating in the Euro. Bringing these markets into the Euro area might have a considerable impact on international portfolio composition.

\section{A Three Currency Scenario}

In this section, I investigate that possibility by distinguishing four different foreign exchange rate scenarios and four European bond market scenarios, yielding a total of sixteen pairs of assumptions. The scenarios closely correspond to those in the previous section. Therefore, the explanation and motivation will be relatively brief.

With respect to the Euro's behavior, the first and third scenarios are identical to the ones in the previous section. In the first one, the Euro is assumed to mimic the past behavior of the German mark ("Euro=DM"), while in the third scenario the Euro behaves as the German mark though with a higher variability ("Euro=DM with high variance"). In the second scenario the Euro behaves like an equally weighed average of four - instead of three - European currencies, the German mark (DM), the French franc (FF), the Italian lira (IL) and the British pound (BP). This is the "Euro $=(\mathrm{FF}+\mathrm{DM}+\mathrm{IL}+\mathrm{BP}) / 4$ " scenario and corresponds to the second Euro-scenario used earlier. The fourth scenario recognizes the potentially dominant effect of the U.K. entry. The Euro again is a weighed average of the four major currencies. However, the weight on the pound is 50 percent, while the continental European countries carry equal weights of 16.6 percent ("Euro=(FF+DM+IL+3BP)/6").

The four corresponding bond market scenarios are first that the bond markets are not affected by the introduction of the Euro. Investors then still choose from a set of six different bonds, of which four now are denominated in the same currency ("4 Euro 
bonds" scenario). However, these remain imperfect substitutes. Note that British, German, French and Italian investors all choose the same portfolio. In the other scenarios the emergence of one large European bond market is assumed. In the second scenario, the typical European bond behaves as the former German bond ("1 Euro bond: GE"). In the third scenario, it is similar to the equally weighted average of British, German, French and Italian bonds ("FR+GE+IT+UK)/4"); in the fourth, the European bond also is a weighted average of the four constituting bonds. However, now the U.K. bond has a weight of 50 percent and the other three bonds each have weight 16.6 percent. Note that the latter three scenarios are logical counterparts to three of the exchange rate scenarios ("FR+GE+IT+3UK)/6") Table 4 contains the results where Panels A through D correspond to the four scenarios with respect to the behavior of the Euro in the foreign exchange market.

[Insert Table 4 here]

For comparison with the benchmark in Table 2 or the previous scenarios in Table 3 , it is important to recognize that the share of Eurobonds and U.K. bonds in investors' portfolios should be aggregated. In Table 4 only three bond categories are distinguished, U.S. bonds, Japanese bonds, and Eurobonds. A first point to note is that U.K. entry into the Euro area leaves Japanese portfolios virtually unchanged across all scenarios. A simple explanation exists. Since U.K. bonds appeared to be unattractive to Japanese investors anyhow in the previous setup, disappearance of this investment option hardly makes a difference. The optimal portfolio of U.S. and European investors on the other hand appears to be quite sensitive to specific bond and foreign exchange market characteristics.

When the Euro starts behaving as the previous German mark with increased variability (Panel C), total demand for Euro-denominated assets is again expected to fall. U.S. investors reduce their Euro holding by approximately 20 percent, Japanese investors by about 2 percent, while European investors reduce their U.S. bond portfolio by about 8 to 9 percent to virtually zero and their Japanese bond portfolio by two or three percent as well. Overall the effect on the Euro is predicted to be negative.

When the Euro exactly has the old German mark characteristics (Panel A), similar effects occur though with some more ambiguity. U.S. investors now reduce their Euro 
portfolio by a similar or slightly higher percentage as European investors decrease their U.S bond holdings. Especially when the European bond market gets integrated and the typical European bond has the characteristics of the German bond, the results for the Euro deteriorate dramatically. U.S. investors strongly decrease their demand for European bonds, while European investors increase their demand for U.S. bonds. The effect would be a depreciation of the Euro relative to the dollar.

The "best" scenarios for the Euro are in Panels B and D. In each of these, the Euro behaves as a weighed average of the four European currencies - especially when the British pound receives a large weight - in combination with an integrated European bond market that behaves as a weighted average of the four constituting national bond markets. In that case, U.S. investors actually increase their demand for European bonds marginally, while European investors marginally decrease their demand for U.S. bonds. Then, a Euro appreciation might occur.

Overall, entry of the U.K. in the Euro area generally leads to qualitatively similar conclusions as with the pound existing parallel to the Euro. Based on a plausible range of scenarios, simple portfolio analysis suggests that a short-run potential of a rise in the value of the Euro appears unlikely.

\section{Actual Supply and Demand in 1999}

It has become clear in the previous sections that for a wide range of plausible developments in Euro foreign exchange markets and European bond markets, a substantial increase in the net demand for Euro-denominated assets internationally is unlikely. The main reason for this is the increase in correlation among European assets and the corresponding decrease in attractive diversification possibilities with respect to Euro-denominated bonds. A substantial increase in depth and liquidity of European bond markets together with lower transaction costs may counteract and offset this effect and generate a higher net demand for European assets. Entry of the U.K. into the Euro area may have a similar effect, especially when the behavior of a representative European bond and the Euro will be influenced by the British pound characteristics considerably. Both events will take time to develop. Overall, the theoretical analysis is consistent with — although not necessarily the reason of — the actual depreciation of the Euro in 1999. 
In this section, I turn to actual supply and demand conditions in international bond markets in the first half of 1999. So far, bond supplies have been assumed exogenous and constant. Here, I reconsider the validity of that assumption and turn to actual international bond issues in 1999. ${ }^{11}$ Subsequently, I use actual characteristics of the Euro foreign exchange market and the European bond markets for the first half year of 1999 to again perform portfolio optimization for representative investors from the different countries. In computing the optimal portfolio, actual covariance structures are used. However, for the expected returns, the same assumptions are made as before. Expected bond returns equal yields to maturity at the end of 1998, while expected currency returns are zero.

\section{International Bond Issues in 1999}

Table 5 contains an overview of international bond and medium-term note issues in 1997, 1998 and the first 3 quarters of 1999. First, Table 5 confirms that limiting the analysis to bonds (and notes) denominated in U.S. dollars, Japanese yen, British pounds and the major European currencies appears appropriate. Issues in other currencies only account for a marginal fraction of the total market. Within the Euro area, the three major currencies account for the large majority of issues in 1997 and 1998. Clearly, after January 1, 1999 Euro-denominated bonds (and notes) are issued, which can not be split up in separate European currencies anymore.

[Insert Table 5 here]

\footnotetext{
${ }^{11}$ A caveat applies. In the analysis, I only consider international bond issues. Government and corporate bond issues in domestic currency are not taken into account. The conclusions thus are conditional on the relative amounts of domestic bond issues in the different countries remaining unaffected.
} 
Second and more importantly, a large shift in relative supplies has taken place at the start of the Euro. In the two years preceding the Euro's introduction, about 60 percent of all long-term debt issues occurred in U.S. dollars, while issues in Euro area currencies accounted for 25 to 30 percent of all issues. The British pound was used in slightly less than 10 percent of the issues. Japanese issues averaged out at almost zero, probably due to the slack performance of the Japanese economy. In 1999, however, relative supplies shifted significantly in favor of Euro bonds and notes. Over the full 3 quarters, new issues of U.S. dollar debt and Euro debt are approximately equal. Apparently, for liability managers, the Euro was the currency of choice in $1999 .{ }^{12}$ Consequently, the relative supply of Euro-denominated bonds and notes increased in 1999. Conditional on international investors' optimal portfolio shares remaining constant, this would imply an excess net supply of Euro assets and would predict a fall of the Euro.

\section{The Optimal 1999 Portfolio}

[Insert Table 6 here]

Table 6 contains summary statistics on bond and foreign exchange returns in the first half year of 1999. In the discussion, I will compare the results in Table 6 for 1999 with those in table 1 for the 1996-1998 period. Part A of Table 6 shows that the mean return on all European bonds, including the U.K., is almost identical at -0.031 per day, that is -8.09 percent annually. This reflects the capital losses on long-term bonds over the sample due to rising yields. For the U.S., the bond return was even lower at -0.060 percent per day or -15.66 percent per year. Only the Japanese bond ex post generated a positive return of 0.020 percent per day or 5.22 percent per year. However, compared to the period 19961998, the standard deviation of Japanese bond returns doubled from 0.304 to 0.611 . The U.S. dollar appreciated against all currencies. Obviously, the three Euro-countries experienced exactly the same depreciation of 0.1 percent per day against the dollar. Both the Yen and the Pound depreciated relative to the dollar, but appreciated relative to the Euro.

\footnotetext{
${ }^{12}$ This holds even stronger for international money market instruments. In the first 3 quarters of 1999 , the market share of Euro-denominated money market issues was about 80 percent, as compared to around 25 percent in the 2 preceding years. The Euro gain came mostly at the expense of the U.S. dollar, see BIS (1999), table 13A.
} 
Part B of Table 6 shows that the correlation coefficients between continentalEuropean bond returns expressed in the joint currency generally increased. However, a fully integrated European bond market with perfectly substitutable bonds has not been obtained yet. In the foreign exchange market, France, Germany and Italy share a common currency. Consequently, their mutual correlation coefficients in part $\mathrm{C}$ equal unity. The correlation of the pound with the other European currencies increased, while the correlation of the Yen with all other currencies decreased. From part D, one may conclude that the correlation between U.S. bond returns and non-U.S. bond returns expressed in dollars has remained virtually the same. However, the correlation between European bonds expressed in dollars has increased considerably. For a U.S. investor, the difference between different European bonds clearly has decreased.

[Insert Table 7 here]

In Table 7 the outcomes of the 1999 portfolio optimization are presented for each country's representative investor. Compared to table 2, a number of changes appear. Apart from the U.S., all countries increase their international diversification. ContinentalEuropean investors have on average increased their foreign - that is non-Euro investments, demanding 4 percentage points more U.S. and 5 percentage points more U.K. bonds. Their Japanese investments on the other hand decline by 3 percentage points. Simultaneously, U.S. investors demand less Euro-bonds and U.K. bonds. Both Japanese and U.K. investors increase their demand for Euro-bonds. Overall, the net change in demand for Euro-bonds is ambiguous. However, it seems reasonable to assume that investors from the Euro area and the U.S. are the largest market participants in absolute portfolio size. The combined effect of increased European demand for U.S. assets and the decreased U.S. demand for European assets will most likely dominate the portfolio shifts emanating from the U.K. and Japan. If so, a depreciation of the Euro relative to the dollar is the predicted outcome in the first half of 1999. Unfortunately, quantifying the degree of depreciation is infeasible on the basis of this analysis. However, the qualitative prediction of the Euro's fall is consistent with actual events. 


\section{Summary and Conclusion}

In this paper, I analyze the consequences of the Euro's introduction for optimal bond portfolios of investors from the major industrialized countries, the U.S., Japan, the U.K., and the three major European countries participating in the Euro, France, Germany and Italy. More over, I investigate the consequences of changes in optimal portfolios for the Euro/dollar spot exchange rate.

Using daily data on constant-maturity government bonds for these 6 countries, as well as bilateral exchange rate data relative to the U.S. dollar for the period 1996-1998, I construct an optimal benchmark portfolio for representative investors from each of the six countries. Each investor uses the same simple quadratic utility function for optimization. Subsequently, I distinguish three plausible (Euro) exchange rate scenarios and three plausible (European) bond market scenarios as a result of the coming of the Euro. Then, the portfolio optimization is implemented again under the nine different combinations with respect to Euro exchange rate and Eurobond characteristics. Generally, the outcomes suggest that an increase in net demand for Euro assets in unlikely, due to the inherent reduction of attractive diversification possibilities. The net demand for Euro bonds is predicted to decline in two cases in particular. This is the case when the Euro/dollar exchange rate becomes more variable than the DM/dollar exchange rate used to be. Secondly, it happens when the Eurobond market becomes so integrated that French, German and Italian bonds become perfect substitutes with characteristics similar to the German bond previously. For a given Eurobond supply this in turn implies a depreciation of the Euro. It is true that the above effects may be counteracted and even be offset by increasing depth and liquidity of European bond markets together with lower transaction costs. These elements have been excluded from the analysis but in principle may increase both the supply and the demand for European assets. The net effect is ambiguous.

Due to the special position of the British pound in world financial markets, a separate set of scenarios is investigated under the assumption that the U.K. will enter the Euro area and will start using the Euro as a currency. The results closely resemble the previous ones. The highest potential for a substantial increase in the net demand for Euro assets is when both the Euro and the typical European bond will behave as weighted 
averages of the constituting national bonds and currencies and the U.K. weight is relatively high.

Finally, actual data for the first half of 1999 are used to assess optimal portfolio behavior. The 1999 data suggest lower demand for Euro assets by U.S investors and higher demand for U.S. assets by European investors. Although both Japanese and U.K. investors increase their demand for Euro assets, the net effect most likely is a decrease in demand for Euro assets. Moreover, actual data on new debt issues in international markets in 1999 show a large shift in favor of Euro-denominated assets, suggesting that the Euro was the currency of choice for liability managers in 1999. Consequently, both actual supply and demand developments in international bond markets in 1999 are consistent with the actual depreciation of the Euro relative to the U.S. dollar. 


\section{REFERENCES}

- Abuaf, Niso and Philippe Jorion. "Purchasing Power Parity in the Long Run," Journal of Finance (March 1990), pp. 157-74.

- Adler, Michael and Bernard Dumas. "International Portfolio Choice and Corporation Finance: A Synthesis," Journal of Finance (June 1983), pp. 925-84.

- Frankel, Jeffrey A., and Andrew K. Rose. "A Panel Project on Purchasing Power Parity: Men Reversion Within and Between Countries," Journal of International Economics (February 1996), pp. 209-24.

- Hartmann, Philipp. Currency Competition and Foreign Exchange Markets: The Dollar, the Yen and the Euro, Cambridge University Press, 1998.

- Heston, Steven L., and K. Geert Rouwenhorst. "Does Industrial Structure Explain the Benefits of International Diversification?” Journal of Financial Economics (August 1994), pp. 3-27.

- Lewis, Karen K. "Puzzles in International Financial Markets," in Handbook of International Economics, Gene M. Grossman and Kenneth Rogoff, eds., NorthHolland, 1995, pp. 1913-71.

"Trying to Explain Home Bias in Equities and Consumption," Journal of Economic Literature (June 1999), pp. 571-608.

- Masson, Paul R., and Bart G. Turtelboom. "Characteristics of the Euro, the Demand for Reserves, and Policy Coordination Under EMU,' International Monetary Fund Working Paper WP/97/58, May 1997.

- McCauley, Robert N. "The Euro and the Dollar", Essays in International Finance, November 1997, No. 205, Princeton University Press.

- McCauley, Robert N., and William R. White. "The Euro and European Financial Markets," Board of Governors of the Federal Reserve System Working Paper, May 1997.

- Ménil, Georges de. "Real Capital Market Integration in the EU: How Far Has It Gone? What Will the Effect of the Euro Be?" Economic Policy (April 1999), pp. 165-89.

- Mussa, Michael. "Nominal Exchange Rate Regimes and the Behavior of Real Exchange Rates: Evidence and Implications," Carnegie-Rochester Conference Series on Public Policy (Autumn 1986), pp. 117-213.

- Portes, Richard and Helene Rey. "The Emergence of the Euro as an International Currency" Economic Policy (April 1998), pp. 305-32.

- Prati, Alessandro and Garry J. Schinasi. "European Monetary Union and International Capital Markets: Structural Implications and Risks," International Monetary Fund Working Paper, May 1997.

- Tavlas, George S. "The International Use of Currencies: The U.S. Dollar and the Euro," Finance and Development (June 1998), pp. 46-49. 
Table 1: Summary Statistics 1996-1998

\begin{tabular}{|c|c|c|c|c|c|c|}
\hline \multirow[t]{2}{*}{ Panel A } & \multicolumn{2}{|c|}{$\begin{array}{c}\text { Bond returns } \\
\text { (own currency; } \\
\text { daily percentages) }\end{array}$} & \multicolumn{2}{|c|}{$\begin{array}{c}\text { \$-exchange rate } \\
\text { returns } \\
\text { (daily percentages) }\end{array}$} & \multicolumn{2}{|c|}{$\begin{array}{c}\text { Bond returns } \\
\text { (in U.S. \$, } \\
\text { daily percentages) }\end{array}$} \\
\hline & Mean & st.dev. & mean & st.dev. & Mean & st.dev. \\
\hline FR & 0.047 & 0.322 & 0.017 & 0.507 & 0.030 & 0.590 \\
\hline GE & 0.040 & 0.308 & 0.019 & 0.522 & 0.021 & 0.606 \\
\hline IT & 0.078 & 0.388 & 0.005 & 0.474 & 0.062 & 0.635 \\
\hline U.K. & 0.054 & 0.385 & -0.009 & 0.447 & 0.062 & 0.635 \\
\hline JP & 0.025 & 0.304 & 0.011 & 0.813 & 0.014 & 0.834 \\
\hline U.S. & 0.029 & 0.409 & - & - & 0.029 & 0.409 \\
\hline \multicolumn{7}{|c|}{ Panel B: correlation matrix of bond returns (in own currency) } \\
\hline & FR & GE & IT & U.K. & JP & U.S. \\
\hline FR & 1 & 0.59 & 0.50 & 0.49 & 0.14 & 0.33 \\
\hline GE & & 1 & 0.62 & 0.36 & 0.17 & 0.21 \\
\hline IT & & & 1 & 0.36 & 0.05 & 0.17 \\
\hline U.K. & & & & 1 & 0.11 & 0.50 \\
\hline JP & & & & & 1 & 0.12 \\
\hline U.S. & & & & & & 1 \\
\hline \multicolumn{7}{|c|}{ Panel C: correlation matrix of \$-exchange rate returns } \\
\hline & FR & GE & IT & U.K. & JP & \\
\hline FR & 1 & 0.99 & 0.89 & 0.43 & 0.43 & \\
\hline GE & & 1 & 0.88 & 0.44 & 0.43 & \\
\hline IT & & & 1 & 0.41 & 0.40 & \\
\hline U.K. & & & & 1 & 0.20 & \\
\hline JP & & & & & 1 & \\
\hline \multicolumn{7}{|c|}{ Panel D: correlation matrix of bond returns (in U.S. dollars) } \\
\hline & FR & GE & IT & U.K. & JP & U.S. \\
\hline$\overline{F R}$ & 1 & 0.87 & 0.68 & 0.44 & 0.34 & 0.16 \\
\hline GE & & 1 & 0.70 & 0.39 & 0.35 & 0.09 \\
\hline IT & & & 1 & 0.37 & 0.26 & 0.10 \\
\hline U.K. & & & & 1 & 0.09 & 0.31 \\
\hline JP & & & & & 1 & -0.08 \\
\hline U.S. & & & & & & 1 \\
\hline
\end{tabular}




\section{Table 2: Optimal Portfolio Allocation; Benchmark 1996-1998}

\begin{tabular}{|l|r|r|r|r|r|r|r|r|r|r|}
\hline & \multicolumn{8}{|c|}{ Holdings (in percentages) by investors from: } \\
\hline Asset holdings: & FR & GE & IT & EUR & U.K. & Japan & \multicolumn{2}{|c|}{ U.S. } \\
\hline French bonds & 38 & 29 & 37 & 35 & 0 & & 4 & & 0 & \\
\hline German Bonds & 44 & 54 & 0 & 33 & 14 & & 0 & & 9 & \\
\hline Italian bonds & 0 & 0 & 41 & 14 & 0 & & 3 & & 9 & \\
\hline \multicolumn{1}{|c}{ European bonds } & 82 & 83 & 78 & 82 & & 14 & & 7 & & 18 \\
\hline U.K. bonds & 0 & 0 & 2 & 1 & & 68 & 0 & & 10 \\
\hline Japanese bonds & 9 & 9 & 10 & 9 & & 11 & 90 & 11 \\
\hline U.S. bonds & 9 & 8 & 10 & 9 & & 6 & & 3 & & 60 \\
\hline
\end{tabular}




\section{Table 3: Optimal Portfolio Allocation: 4 Currency Scenario}

\begin{tabular}{|c|c|c|c|c|c|c|c|c|c|c|c|}
\hline \multirow{2}{*}{\multicolumn{12}{|c|}{$\begin{array}{l}\text { Panel A } \\
\text { Euro scenario } \\
\end{array}$}} \\
\hline & & & & & & & & & & & \\
\hline \multirow[t]{3}{*}{ Bond scenario } & \multicolumn{4}{|c|}{$\begin{array}{l}3 \text { Euro bonds: } \\
\text { FR, GE, IT }\end{array}$} & \multicolumn{4}{|c|}{$\begin{array}{l}1 \text { Euro bond: } \\
\text { GE }\end{array}$} & \multicolumn{3}{|c|}{$\begin{array}{l}1 \text { Euro bond: } \\
(\mathrm{FR}+\mathrm{GE}+\mathrm{IT}) / 3\end{array}$} \\
\hline & \multicolumn{11}{|c|}{ Holdings (in percentages) by investors from: } \\
\hline & EU & UK & JP & US & EU & UK & JP & US & EU & UK & $\mathrm{JP}$ \\
\hline Euro bonds & 84 & 14 & 8 & 17 & 77 & 14 & 5 & 16 & 84 & 14 & 7 \\
\hline U.K. bonds & 0 & 68 & 0 & 11 & 3 & 68 & 0 & 12 & 0 & 68 & 0 \\
\hline JP bonds & 9 & 11 & 90 & 11 & 10 & 11 & 91 & 11 & 9 & 11 & 90 \\
\hline U.S. bonds & 7 & 6 & 2 & 61 & 10 & 6 & 4 & 61 & 7 & 6 & 3 \\
\hline \multicolumn{12}{|l|}{ Panel B } \\
\hline Euro scenario & \multicolumn{11}{|c|}{ Euro $=(\mathrm{FF}+\mathrm{DM}+\mathrm{IL}) / 3$} \\
\hline \multirow[t]{3}{*}{ Bond scenario } & \multicolumn{4}{|c|}{$\begin{array}{l}3 \text { Euro bonds: } \\
\text { FR, GE, IT }\end{array}$} & \multicolumn{4}{|c|}{$\begin{array}{c}1 \text { Euro bond: } \\
\text { GE }\end{array}$} & \multicolumn{3}{|c|}{$\begin{array}{l}1 \text { Euro bond: } \\
(\mathrm{FR}+\mathrm{GE}+\mathrm{IT}) / 3\end{array}$} \\
\hline & \multicolumn{11}{|c|}{ Holdings (in percentages) by investors from: } \\
\hline & EU & UK & JP & US & EU & UK & $\mathrm{JP}$ & US & EU & UK & JP \\
\hline Euro bonds & 82 & 14 & 7 & 19 & 74 & 14 & 5 & 17 & 80 & 13 & 7 \\
\hline U.K. bonds & 0 & 68 & 0 & 10 & 4 & 68 & 0 & 11 & 1 & 69 & 0 \\
\hline JP bonds & 9 & 11 & 90 & 11 & 11 & 11 & 91 & 11 & 10 & 12 & 90 \\
\hline U.S. bonds & 9 & 6 & 3 & 60 & 11 & 6 & 4 & 61 & 9 & 6 & 3 \\
\hline \multicolumn{12}{|l|}{ Panel C } \\
\hline Euro scenario & \multicolumn{11}{|c|}{ Euro $=$ DM with high variance } \\
\hline \multirow[t]{3}{*}{ Bond scenario } & \multicolumn{4}{|c|}{$\begin{array}{l}3 \text { Euro bonds: } \\
\text { FR, GE, IT }\end{array}$} & \multicolumn{4}{|c|}{$\begin{array}{c}1 \text { Euro bond: } \\
\text { GE } \\
\end{array}$} & \multicolumn{3}{|c|}{$\begin{array}{l}1 \text { Euro bond: } \\
(\mathrm{FR}+\mathrm{GE}+\mathrm{IT}) / 3\end{array}$} \\
\hline & \multicolumn{11}{|c|}{ Holdings (in percentages) by investors from: } \\
\hline & EU & UK & JP & US & $\mathrm{EU}$ & UK & JP & US & EU & UK & JP \\
\hline Euro bonds & 92 & 8 & 5 & 4 & 88 & 8 & 4 & 3 & 93 & 8 & 5 \\
\hline U.K. bonds & 0 & 70 & 0 & 17 & 0 & 70 & 0 & 17 & 0 & 70 & 0 \\
\hline JP bonds & 7 & 12 & 90 & 14 & 8 & 12 & 91 & 15 & 6 & 12 & 90 \\
\hline U.S. bonds & 1 & 10 & 4 & 65 & 4 & 10 & 5 & 65 & 1 & 10 & 5 \\
\hline
\end{tabular}




\section{Table 4: Optimal Portfolio Allocation: 3 Currency Scenario}

\begin{tabular}{|c|c|c|c|c|c|c|c|c|c|c|c|c|}
\hline \multirow{3}{*}{$\begin{array}{l}\text { Panel A } \\
\text { Euro scenario } \\
\text { Bond scenario }\end{array}$} & & & & & & & & & & & & \\
\hline & \multicolumn{12}{|c|}{ Euro $=\mathrm{DM}$} \\
\hline & \multicolumn{3}{|c|}{$\begin{array}{l}4 \text { Euro bonds: } \\
\text { FR, GE, IT, UK }\end{array}$} & \multicolumn{3}{|c|}{$\begin{array}{l}1 \text { Euro bond: } \\
\text { GE }\end{array}$} & \multicolumn{3}{|c|}{$\begin{array}{c}1 \text { Euro bond: } \\
(\mathrm{FR}+\mathrm{GE}+\mathrm{IT}+\mathrm{UK}) / 4\end{array}$} & \multicolumn{3}{|c|}{$\begin{array}{c}1 \text { Euro bond: } \\
(\mathrm{FR}+\mathrm{GE}+\mathrm{IT}+3 \mathrm{UK}\end{array}$} \\
\hline & \multicolumn{12}{|c|}{ Holdings (in percentages) by investors from: } \\
\hline & EU & $\mathrm{JP}$ & US & EU & JP & US & EU & JP & US & EU & $\mathrm{JP}$ & \\
\hline Euro bonds & 87 & 8 & 22 & 78 & 5 & 20 & 88 & 7 & 21 & 87 & 7 & \\
\hline JP bonds & 9 & 90 & 11 & 10 & 91 & 12 & 9 & 90 & 12 & 11 & 91 & \\
\hline U.S. bonds & 4 & 2 & 67 & 12 & 4 & 68 & 3 & 3 & 67 & 2 & 3 & \\
\hline \multicolumn{13}{|l|}{ Panel B } \\
\hline Euro scenario & \multicolumn{12}{|c|}{ Euro $=(\mathrm{FF}+\mathrm{DM}+\mathrm{IL}+\mathrm{BP}) / 4$} \\
\hline \multirow[t]{3}{*}{ Bond scenario } & \multicolumn{3}{|c|}{$\begin{array}{l}4 \text { Euro bonds: } \\
\text { FR, GE, IT, UK }\end{array}$} & \multicolumn{3}{|c|}{$\begin{array}{l}\text { Euro bond: } \\
\text { GE }\end{array}$} & \multicolumn{3}{|c|}{$\begin{array}{c}1 \text { Euro bond: } \\
(\mathrm{FR}+\mathrm{GE}+\mathrm{IT}+\mathrm{UK}) / 4\end{array}$} & \multicolumn{3}{|c|}{$\begin{array}{c}1 \text { Euro bond: } \\
(\mathrm{FR}+\mathrm{GE}+\mathrm{IT}+3 \mathrm{UK}\end{array}$} \\
\hline & \multicolumn{12}{|c|}{ Holdings (in percentages) by investors from: } \\
\hline & EU & $\mathrm{JP}$ & US & EU & JP & US & EU & JP & US & EU & JP & \\
\hline Euro bonds & 82 & 7 & 28 & 72 & 4 & 27 & 82 & 6 & 28 & 82 & 6 & \\
\hline JP bonds & 10 & 91 & 10 & 11 & 91 & 10 & 11 & 91 & 11 & 12 & 91 & \\
\hline U.S. bonds & 8 & 3 & 62 & 16 & 4 & 63 & 7 & 3 & 61 & 6 & 3 & \\
\hline \multicolumn{13}{|l|}{ Panel C } \\
\hline Euro scenario & \multicolumn{12}{|c|}{ Euro $=$ DM with high variance } \\
\hline \multirow[t]{3}{*}{ Bond scenario } & \multicolumn{3}{|c|}{$\begin{array}{l}4 \text { Euro bonds: } \\
\text { FR, GE, IT, UK }\end{array}$} & \multicolumn{3}{|c|}{$\begin{array}{l}1 \text { Euro bond: } \\
\text { GE }\end{array}$} & \multicolumn{3}{|c|}{$\begin{array}{c}1 \text { Euro bond: } \\
(\mathrm{FR}+\mathrm{GE}+\mathrm{IT}+\mathrm{UK}) / 4\end{array}$} & \multicolumn{3}{|c|}{$\begin{array}{c}1 \text { Euro bond: } \\
(\mathrm{FR}+\mathrm{GE}+\mathrm{IT}+3 \mathrm{UK}\end{array}$} \\
\hline & \multicolumn{12}{|c|}{ Holdings (in percentages) by investors from: } \\
\hline & EU & $\mathrm{JP}$ & US & $\mathrm{EU}$ & JP & US & EU & JP & US & EU & JP & \\
\hline Euro bonds & 93 & 5 & 9 & 88 & 4 & 8 & 93 & 5 & 7 & 92 & 5 & \\
\hline JP bonds & 7 & 90 & 15 & 8 & 91 & 15 & 7 & 91 & 16 & 8 & 91 & \\
\hline U.S. bonds & 0 & 4 & 76 & 4 & 5 & 77 & 0 & 5 & 77 & 0 & 5 & \\
\hline \multicolumn{13}{|l|}{ Panel D } \\
\hline Euro scenario & \multicolumn{12}{|c|}{ Euro $=(\mathrm{FF}+\mathrm{DM}+\mathrm{IL}+3 \mathrm{BP}) / 6$} \\
\hline \multirow[t]{3}{*}{ Bond scenario } & \multicolumn{3}{|c|}{$\begin{array}{l}4 \text { Euro bonds: } \\
\text { FR, GE, IT, UK }\end{array}$} & & $\begin{array}{l}\text { o bo } \\
\mathrm{JE}\end{array}$ & & $\begin{array}{r}1 \\
(\mathrm{FR}+ \\
\end{array}$ & $\begin{array}{l}\text { ro bor } \\
+\mathrm{IT}+\end{array}$ & ) $/ 4$ & $\begin{array}{r}1 \\
(\mathrm{FR}+( \\
\end{array}$ & $\begin{array}{l}\text { o bon } \\
\text {-IT }+3 \\
\end{array}$ & ad: \\
\hline & & & & Iold & (in 1 & centa & s) by $\mathrm{i}$ & restors & om: & & & \\
\hline & EU & $\mathrm{JP}$ & US & EU & $\mathrm{JP}$ & US & EU & JP & US & EU & JP & \\
\hline Euro bonds & 82 & 6 & 30 & 72 & 3 & 29 & 82 & 5 & 31 & 81 & 5 & \\
\hline JP bonds & 10 & 91 & 10 & 11 & 92 & 10 & 10 & 91 & 11 & 12 & 91 & \\
\hline U.S. bonds & 8 & 3 & 60 & 18 & 5 & 61 & 8 & 3 & 59 & 7 & 4 & \\
\hline
\end{tabular}




\section{Table 5: Characteristics of International Debt Issues}

\begin{tabular}{|c|c|c|c|c|c|c|}
\hline & \multicolumn{5}{|c|}{$\begin{array}{l}\text { Net issues of bonds and medium-term notes } \\
\text { (billions of U.S. dollars) }\end{array}$} & \multirow{2}{*}{$\begin{array}{l}\begin{array}{l}\text { Stocks } \\
\text { (bln. U.S.\$) }\end{array} \\
\text { End-Sept. } 1999\end{array}$} \\
\hline & 1997 & 1998 & & 1999 & & \\
\hline Currency: & & & Q1 & Q2 & Q3 & \\
\hline US dollar & 293.4 & 398.9 & 132.3 & 152.1 & 114.3 & $2,126.5$ \\
\hline Yen & 28.2 & -24.2 & -11.8 & -3.5 & 6.1 & 493.1 \\
\hline Euro area & 128.4 & 203.1 & 83.5 & 134.7 & 139.7 & $1,356.6$ \\
\hline UK pound & 46.8 & 57.0 & 17.6 & 26.5 & 20.6 & 389.3 \\
\hline Other & 21.9 & 17.9 & 4.8 & 11.9 & -0.2 & 287.8 \\
\hline Total & 518.7 & 652.7 & 226.4 & 321.7 & 280.5 & $4,653.3$ \\
\hline
\end{tabular}

Source: BIS Quarterly Review, "International Banking and Financial Market Developments," November 1999, table 13B. For the U.K., the entries contain (a quantitatively unimportant amount of) equity-related bond and note issues. 
Table 6: Summary Statistics 1999

\begin{tabular}{|c|c|c|c|c|c|c|}
\hline \multirow[t]{2}{*}{ Panel A } & \multicolumn{2}{|c|}{$\begin{array}{c}\text { Bond returns } \\
\text { (own currency, } \\
\text { daily percentages) }\end{array}$} & \multicolumn{2}{|c|}{$\begin{array}{c}\text { \$-exchange rate } \\
\text { returns } \\
\text { (daily percentages) }\end{array}$} & \multicolumn{2}{|c|}{$\begin{array}{c}\text { Bond returns } \\
\text { (in U.S. \$, } \\
\text { daily percentages) }\end{array}$} \\
\hline & mean & st.dev. & mean & st.dev. & Mean & st.dev. \\
\hline FR & -0.031 & 0.382 & 0.100 & 0.519 & -0.131 & 0.695 \\
\hline GE & -0.031 & 0.385 & 0.100 & 0.519 & -0.131 & 0.709 \\
\hline IT & -0.031 & 0.333 & 0.100 & 0.519 & -0.131 & 0.666 \\
\hline U.K. & -0.032 & 0.393 & 0.040 & 0.387 & -0.073 & 0.522 \\
\hline $\mathrm{JP}$ & 0.020 & 0.611 & 0.055 & 0.797 & -0.035 & 0.852 \\
\hline U.S. & -0.060 & 0.437 & - & - & -0.060 & 0.437 \\
\hline \multicolumn{7}{|c|}{ Panel B: correlation matrix of bond returns (in own currency) } \\
\hline & FR & GE & IT & U.K. & $\mathrm{JP}$ & U.S. \\
\hline FR & 1 & 0.63 & 0.72 & 0.62 & 0.00 & 0.33 \\
\hline GE & & 1 & 0.88 & 0.25 & 0.16 & 0.08 \\
\hline IT & & & 1 & 0.45 & 0.16 & 0.25 \\
\hline U.K. & & & & 1 & 0.03 & 0.55 \\
\hline JP & & & & & 1 & 0.06 \\
\hline U.S. & & & & & & 1 \\
\hline \multicolumn{7}{|c|}{ Panel C: correlation matrix of \$-exchange rate returns } \\
\hline & FR & GE & IT & U.K. & $\mathrm{JP}$ & \\
\hline FR & 1 & 1 & 1 & 0.56 & 0.23 & \\
\hline GE & & 1 & 1 & 0.56 & 0.23 & \\
\hline IT & & & 1 & 0.56 & 0.23 & \\
\hline U.K. & & & & 1 & 0.16 & \\
\hline $\mathrm{JP}$ & & & & & 1 & \\
\hline \multicolumn{7}{|c|}{ Panel D: correlation matrix of bond returns (in U.S. dollars) } \\
\hline & FR & GE & IT & U.K. & $\mathrm{JP}$ & U.S. \\
\hline FR & 1 & 0.89 & 0.92 & 0.56 & 0.14 & 0.19 \\
\hline $\mathrm{GE}$ & & 1 & 0.97 & 0.43 & 0.20 & 0.05 \\
\hline IT & & & 1 & 0.50 & 0.21 & 0.13 \\
\hline U.K. & & & & 1 & 0.14 & 0.46 \\
\hline JP & & & & & 1 & -0.11 \\
\hline U.S. & & & & & & 1 \\
\hline
\end{tabular}




\section{Table 7: Optimal Portfolio Allocation 1999}

\begin{tabular}{|l|r|r|r|r|r|r|r|r|}
\hline & \multicolumn{6}{|c|}{ Holdings (in percentages) by investors from: } \\
\hline Holdings of: & \multicolumn{2}{|c|}{ EUR } & \multicolumn{1}{|l|}{ U.K. } & \multicolumn{2}{|l|}{ Japan } & \multicolumn{2}{l|}{ U.S. } \\
\hline French bonds & 19 & & 0 & & 10 & & 0 & \\
\hline German bonds & 12 & & 18 & & 0 & & 15 & \\
\hline Italian bonds & 44 & & 0 & & 0 & & 0 & \\
\hline \multicolumn{1}{|c|}{ European bonds } & & 75 & & 18 & & 10 & 15 \\
\hline U.K. bonds & & 6 & & 60 & & 19 & 8 \\
\hline Japanese bonds & & 6 & & 7 & & 70 & 15 \\
\hline U.S. bonds & & 13 & & 15 & & 1 & 62 \\
\hline
\end{tabular}


